Ingrid Rodrick Beiler*

\title{
Marked and unmarked translanguaging in accelerated, mainstream, and sheltered English classrooms
}

https://doi.org/10.1515/multi-2020-0022

\begin{abstract}
Translanguaging has gained prominence as a way to understand multilingual practices and draw on these in additional language teaching, but questions remain regarding its application in various educational contexts. This study investigates the significance of translanguaging across instructional settings by comparing discourses of markedness in accelerated, mainstream, and sheltered classes taught by the same teacher, where both linguistically majoritized and minoritized students were learning English as an additional language. Data are drawn from four months of linguistic ethnographic fieldwork at a Norwegian upper secondary school and include field notes, video and screen recordings, texts, language portraits, and teacher and student interviews. I found that translanguaging was marked in two largely separate ways: (1) bilingual English-Norwegian practices were more frequently marked in accelerated and mainstream settings, in relation to students' perceived English proficiency level; whereas (2) translanguaging drawing on minoritized languages was more consistently marked in all three settings as a deviation from majority linguistic practices, thus distinguishing majoritized (English-Norwegian) from minoritized translanguaging. Implications include the importance of analyzing translanguaging in relation to locally salient discourses and contextualizing pedagogical interventions in larger struggles for justice.
\end{abstract}

Keywords: translanguaging, markedness, language education, multilingualism, monoglossic ideologies, raciolinguistic ideologies

Correction Note: Correction added after online publication September 11, 2020: The line numbers in all Excerpts and all references to them in the text were updated, because not all author corrections were implemented during production.

*Corresponding author: Ingrid Rodrick Beiler, Department of Teacher Education and School Research, University of Oslo Faculty of Education, PO Box 1099, Blindern, 0317, Oslo, Norway, E-mail: i.r.beiler@ils.uio.no. https://orcid.org/0000-0002-9660-5156 
Translanguaging has spread rapidly in the past decade as a term to describe language practices that surpass perceived language boundaries, as well as pedagogical approaches that build on such language practices (e.g., Cenoz and Gorter 2017; García 2009; García and Li Wei 2014). First developed to promote Welsh-English bilingualism (Williams 1994) and then applied more broadly to the education of linguistically minoritized students (e.g., Creese and Blackledge 2015; García 2009; García and Li Wei, 2014; Hornberger and Link 2012; Makalela 2015), translanguaging offers the potential of a linguistically inclusive and empowering pedagogy. However, questions remain regarding its application across various contexts, involving both linguistically majoritized and minoritized students and prestigious as well as minoritized languages (Leung and Valdés 2019; Turner and Lin 2017). As translanguaging and other multilingual approaches gain ground, some have also expressed concerns that the desire to redress power imbalances that inspired these approaches may recede, with a resulting focus on linguistic hybridity rather than social justice (e.g., Jaspers 2018; Kubota 2016).

The current study aims to make an empirical and theoretical contribution to debates concerning translanguaging in additional language education by comparing patterns and discourses of translanguaging in three English classes taught by the same teacher, using the same curriculum, where one is an accelerated class, one a mainstream class, and one a sheltered class for recent immigrants who have struggled with the subject. Relatively little research has been conducted on translanguaging in mainstream settings (cf. Duarte 2019; Rosiers et al. 2018), and comparison of translanguaging across learner groups appears to be even rarer (cf. Rosiers et al. 2018). Situated in Norway, where English is a high-stakes additional language subject for both linguistically majoritized and minoritized students, this comparative approach brings to the fore different discourses that mark translanguaging in relation to contexts, participants, and resources. In this article, I first discuss translanguaging as a theoretical and educational proposal. I then present markedness (e.g., Flores and Rosa 2015, 2019; Meeuwis and Blommaert 1994; Myers-Scotton 1993) as an analytical concept for classroom translanguaging. Next, I situate English teaching in the context of multilingualism in Norway, before presenting the research design and findings of the study. Finally, I discuss the need to interpret classroom translanguaging in light of the discourses that are made salient in specific additional language teaching contexts and student groups.

\section{Translanguaging as a theoretical and educational approach}

Translanguaging can be seen as both a theoretical and an educational proposal (García 2009; García and Li Wei 2014). Drawing on Williams's (1994) concept of 
trawsieithu (translanguaging in English), which referred to strategic alternation of languages in bilingual Welsh-English education, García (2009) extended translanguaging to the domain of everyday language use: "translanguagings are the multiple discursive practices in which bilinguals engage in order to make sense of their bilingual worlds" (p. 45, italics in the original). This definition includes boundary-crossing language practices that had until then been described as codeswitching (e.g., Meeuwis and Blommaert 1994; Myers-Scotton 1993). However, translanguaging introduces a repertoire perspective, whereby the focus is no longer on codes, such as languages or dialects, but rather on how speakers draw on their full linguistic repertoires for sense-making (Busch 2012; García 2009). This shift reflects a view that communication and identities cannot be reduced to systematic alternation between codes (Canagarajah 2013; Creese and Blackledge 2015). Unlike code-switching, translanguaging and translingual practices also include the ways that bodily and spatial resources are used alongside language (Canagarajah 2013, 2018; Li Wei 2018).

Translanguaging has also developed as a critical educational approach, based on the needs of linguistically marginalized learners, including speakers of regional minority languages (e.g., Cenoz and Gorter 2017; Williams 1994) and racialized or otherwise linguistically minoritized students (Creese and Blackledge 2015; García and Li Wei 2014; García and Otheguy 2020; Hornberger and Link 2012; Makalela 2015). Importantly, teachers can encourage students to draw on translanguaging practices, even if they do not share their linguistic repertoires (García and Kleyn 2016; Mary and Young 2017). García and Kano (2014) have further suggested that translanguaging in education can "give voice to new sociopolitical realities by interrogating linguistic inequality” (p. 261). This assertion is based on two widely observed facets of societal language hierarchies: on the one hand, monolingual ideologies, which identify mastery of a national majority language with political legitimacy and belonging; on the other hand, monoglossic ideologies, which value a specific kind of multilingualism in which languages are kept "pure" and separate (Canagarajah 2013; García and Li Wei 2014; Makalela 2015; Piller and Takahashi 2011). Thus, translanguaging is not simply proposed as a more effective means of language learning, but as a rejection of hegemonic political and educational ideologies (García and Li Wei 2014; Makalela 2015).

However, some have raised questions as to whether pedagogical translanguaging necessarily challenges societal inequalities. One critique relates to potential negligence of economic or racial inequalities that belie linguistic inequality (e.g., Block 2018; Flores et al. 2018; Jaspers 2018). Others have raised questions about the applicability of translanguaging to both linguistically majoritized and minoritized students, across various additional language teaching contexts (Cenoz and Gorter 2017; Leung and Valdés 2019; Turner and Lin 2017). The 
latter issue relates partly to whether named-and taught-languages can relate to translanguaging only as objects of disruption, or perhaps also as elements of an expanding linguistic repertoire, notably for students who are participating in efforts to sustain a vulnerable minority language (Cenoz and Gorter 2017) or who may never have their own monolingual norm challenged without instruction in additional languages (Turner and Lin 2017). Furthermore, Allard (2017) demonstrated that translanguaging may fall short of its emancipatory aims if other factors in the institutional and societal language ecology do not support transformative bilingual development.

There also remain questions about how to identify translanguaging empirically, apart from reference to the named languages whose primacy much translanguaging scholarship has sought to destabilize. Translanguaging has usually been identified in practices that might conventionally be described as bilingual or multilingual (e.g., Duarte 2019; García and Kleyn 2016; Mary and Young 2017), but this is theoretically only the case because of a focus on learners who are stigmatized for using resources identified with multiple languages, rather than racialized or working-class varieties of a majority language (cf. Flores and Rosa 2015; Rosiers et al. 2018). Another approach has been to identify translanguaging in critical or creative language use that plays with transgression of linguistic categories such as languages or registers (Baynham and Lee 2019; Li Wei 2018). Both approaches incorporate the idea of translanguaging as superseding boundaries and categories. As Hawkins and Mori (2018) note, “these terms with the 'trans-' prefix at once advocate for the appreciation of fluidity and flexibility seen in contemporary society and underscore the very existence of categories, borders, and boundaries that are called into question" (p. 1). Thus, translanguaging indexes fixed discourses even as it challenges these. In the following section, I suggest that markedness (e.g., Flores and Rosa 2015, 2019; Meeuwis and Blommaert 1994; Myers-Scotton 1993) can be useful for understanding translanguaging in relation to the specific locally salient discourses it challenges or transcends.

\section{Markedness and translanguaging}

Markedness has been applied to both translanguaging and code-switching in reference to characteristics such as the usualness or expectedness of language use under given circumstances (e.g., Creese and Blackledge 2015; Myers-Scotton 1993). Markedness has even been proposed as a way to distinguish translanguaging from code-switching, but without agreement on the nature of the distinction. Baynham and Lee (2019) describe translanguaging as more inherently marked than codeswitching, emphasizing the critical and creative dimensions of translanguaging. In 
contrast, Creese and Blackledge (2015) write that "translanguaging practices are not viewed as marked or unusual, but are rather taken to be the normal mode of communication that characterizes communities throughout the world," (p. 28), foregrounding the everyday nature of translanguaging (see also García 2009). I therefore suggest that translanguaging may be marked or unmarked to varying degrees, as Myers-Scotton (1993) proposed earlier with regard to code-switching.

If translanguaging may be marked or unmarked, there remain questions about what or who determine markedness. In Myers-Scotton's (1993) model, the markedness of code-switching is based on "the norms of the society regarding the salience of specific situational factors present” (p. 152). This backdrop of speech community norms allows speakers to deploy and interpret linguistic codes-or indeed, code-switching itself-as unremarkable (unmarked) or as a renegotiation of identities and relationships (marked), based on the indexical values of codes (Myers-Scotton 1993). Although listeners are implied, the model is speakercentered (Myers-Scotton 1993), and indeed Meeuwis and Blommaert (1994) critique the model for neglecting social context by explaining code choices exclusively in terms of speaker motivations. Other premises of the model, including homogenous and stable speech communities as givers of norms and indeed stable codes themselves, have also been critiqued as too static (e.g., Canagarajah 2013; Meeuwis and Blommaert 1994). Rather than simply mirroring speech community norms, markedness should be seen as situated and emergent, requiring ethnographic evidence of its local significance (Meeuwis and Blommaert 1994). Thus, instances where translanguaging is marked as significant by participants, for instance through comments, bodily orientation, or prosodic features, may provide insight into locally salient discourses of language use.

Furthermore, recent work highlights markedness as a property ascribed by language ideologies of perception, rather than constituting neutral grounds for speakers' choices (Daugaard and Laursen 2012; Flores et al. 2018; Flores and Rosa 2015, 2019). In such usage, markedness often implies more specifically a negative evaluation. Flores and Rosa (2015) contend that markedness often resides in raciolinguistic ideologies that define and conflate racialized speakers with linguistic deficiency, independent of empirically observable language practices. As a result, "white speaking subjects are afforded the opportunity to engage in language practices that are unmarked or even celebrated while racialized speaking subjects are policed for engaging in similar language practices" (Flores and Rosa 2019 , p. 148). One common variant of such raciolinguistic ideologies is a naturalized divide between ways of communicating that are deemed appropriate in school, implicitly modeled after white speakers, while racialized ways of communicating may be framed as belonging in the home (Flores and Rosa 2015). Building on Inoue's (2003) concept of the listening subject, Flores and Rosa (2015, 
2019) therefore argue for paying attention to the white listening subject to which speakers may orient, seen not simply in which but in whose linguistic practices are treated as marked and unmarked. Flores and Rosa (2015) emphasize that the white listening subject is a dominant ideological mode of perception, rather than a biographical individual. Indeed, both white and racialized individuals may inhabit or enact a white listening subject position, as allowed by socio-historical processes (Rosa and Flores 2017). Raciolinguistic ideologies also operate in concert with other dimensions of inequality such as gender, class, and nationality that may influence perceptions of speakers' deficiency or legitimacy (Rosa and Flores 2017).

In a Norwegian school context, Connor (2019) identifies white "ethnic Norwegians" (p. 57) as the dominant listening subject, which may perceive as noise the voices and languages of "foreign migrants" (p. 63). This may be considered a more specific form of imagined white Europeanness (Rosa and Flores 2017), aligned with a monoglossic Norwegian national language ideology and defined in opposition to more or less visible-or racialized-foreignness, as well as minorities such as Jewish, Roma, and indigenous Sami people (Dowling 2017; Lindquist and Osler 2016). In Connor's (2019) study, the migrant students themselves orient to an "ethnic Norwegian" regime of hearing by reacting to their classmates' languages as incomprehensible "strange sounds" (p. 62) when their teacher tries to have students read aloud poetry they have written in Norwegian and their "native" languages. These students may be seen as temporarily enacting a white listening subject position despite their own marginalization (Rosa and Flores 2017).

In sum, examining patterns of unmarked and marked translanguaging may provide information about dominant language ideologies and whose translanguaging is seen as unremarkable or notable in school. As noted in the previous section, translanguaging definitionally challenges monolingual and monoglossic ideologies. However, not all bilingualism or multilingualism is similarly evaluated (Flores and Rosa 2015, 2019; García and Otheguy 2020; Ortega 2019), and even linguistic fluidity can index different experiences and places in society, from powerful neoliberal cosmopolitanism to stigmatized migrant multilingualism (Jaspers 2018; Kubota 2016). In this vein, Leung and Valdés (2019) have called for research that helps to clarify the dynamics of translanguaging across different types of additional language teaching, beyond those from which it arose, that is, minority language revitalization and majority language instruction for linguistically minoritized students. They do so in part by identifying various types of additional language teaching aimed at "mainstream" and "minority" language learners, identifying translanguaging as an approach that arose in "language instruction directed at minority learners” (Leung and Valdés 2019, p. 351). I will now present the context and design of the present study, which compares patterns and discourses of translanguaging across such learner groups. The study furthermore 
incorporates a focus on writing instruction, which appears to have received relatively less focus in research on classroom translanguaging (although see e.g., Beiler 2020; Beiler and Dewilde 2020; Canagarajah 2013; García and Kano 2014; Seltzer 2019).

\section{Study context and participants}

In Norway, English has no official legal status, but it has become an important language in personal, professional, and educational domains, such that some argue that English is becoming closer to a second than a foreign language (Brevik and Rindal 2020; Rindal 2014). English is a core school subject for all students from grades 1-11 (ca. ages 6 to 17), and passing English is required to receive an upper secondary diploma at the end of grade 13. Following the model of traditional foreign language teaching, English has largely been conceived of as a subject for "mainstream students," as opposed to an offer specifically for "minority language learners” (Leung and Valdés 2019, pp. 351-352), like supplemental Norwegian instruction. However, English teaching in Norway is in fact sometimes targeted specifically at linguistically minoritized learners, in this case recent immigrants. This scenario may arise in introductory classes, where the focus is on learning enough Norwegian to transition to mainstream instruction, but where English may also be taught as a subject (Beiler 2020; Burner and Carlsen 2019; Krulatz and Iversen 2019). Since placement in introductory classes is based on Norwegian proficiency, students' English proficiency may vary widely (Beiler 2020; Burner and Carlsen 2019). Another case may occur in upper secondary schools (grades 1113), which may choose to organize supplemental English instruction for students who are also receiving supplemental Norwegian instruction (Ministry of Education and Research 1998, §3-12). In this case, supplemental English instruction is based on individual evaluation, typically given to students who received less English instruction in their previous countries of residence than their grade-level peers in Norway. These students may thus find themselves in a position as minoritized language learners in the teaching of not only Norwegian but also English.

There is no officially mandated language of instruction for English teaching in Norway, but research suggests that teachers aspire to teach largely in English, though recourse to Norwegian for scaffolding is common (Brevik and Rindal 2020; Burner and Carlsen 2019; Scheffler et al. 2017). The 2013 national English curriculum (in force at the time of data collection) also implicitly opens for the use of other languages by referring generically to students' "native language" rather than assuming this to be Norwegian in competence aims that call for making comparisons with English (Norwegian Directorate for Education and Training 2013). 
Nonetheless, most Norwegian studies have indicated that students' multilingual resources are used minimally if at all in English teaching in both mainstream and introductory classes (e.g., Brevik and Rindal 2020; Burner and Carlsen 2019; Flognfeldt 2018; Krulatz and Torgersen 2016; for exceptions, see Beiler 2020; Krulatz and Iversen 2019). In two introductory classes, Beiler (2020) found that translanguaging at the level of the whole class drew mostly on Norwegian and English, while students' multilingual repertoires were most fully used in individual writing practices and peer interactions. The current study builds on this finding by also focusing on writing practices and writing instruction, though not exclusively so. To the best of my knowledge, few studies have compared the language practices of a single teacher across various student groups, and no previous study has investigated supplemental English instruction for recent immigrants in upper secondary school in Norway.

The current study adds a comparative dimension to the study of classroom translanguaging by examining patterns and discourses of language use in three English classes taught by the same teacher, following the same national curriculum, but composed of three groups that were distinguished by previous subject achievement: a mainstream grade 11 English class, an accelerated class taking the course one year early based on high subject achievement, and a sheltered class for recent immigrants repeating the course based on low achievement in the previous year. These three classes and participant numbers are summarized in Table 1.

As presented in Table 1, there were 54 student participants in total, including 14 students designated as "minority language speakers." I determined through fieldwork that this term was used at the school to refer to students who were receiving supportive Norwegian instruction. These students had generally immigrated to Norway in lower secondary school or later. The "mainstream" class represents the English course that all grade 11 students in general studies are required to take, and the class included students at a variety of English proficiency levels. Five students in the class were designated as "minority language speakers" and were placed in the

Table 1. Participating classes and students.

\begin{tabular}{|c|c|c|c|c|}
\hline Class type & Accelerated & Mainstream & Sheltered & Total \\
\hline Class description & $\begin{array}{l}\text { High-achieving }^{\mathrm{a}} \\
\text { grade } 10 \text { students }\end{array}$ & $\begin{array}{l}\text { Mixed achievement } \\
\text { levels } ; \text { grade } \\
11 \text { students }\end{array}$ & $\begin{array}{l}\text { Low-achieving }^{\text {a }} \\
\text { grade } 12 / 13 \\
\text { students }\end{array}$ & \\
\hline $\begin{array}{l}\text { “Minority language } \\
\text { speakers” (subset) }\end{array}$ & 4 & 5 & 5 & $n=14$ \\
\hline Students (total) & 23 & 25 & 6 & $N=54$ \\
\hline
\end{tabular}

${ }^{a}$ Notes. The description applies only to English, not to general academic achievement. 
class based on a district-level mainstreaming policy. Four students with advanced English proficiency who were enrolled in introductory classes at the school joined the accelerated class part-time toward the end of the study. In contrast, the sheltered class was specifically an offer for "minority language speakers," thus comparable to Leung and Valdés's (2019) "language instruction directed at minority learners" (p. 352). This class also included one visually impaired student, who had completed all of his other course requirements and was taking English in a setting that allowed for more personal attention.

The recently immigrated students came from a variety of countries in Africa, Asia, Europe, and the Middle East. In addition, many of the students in the accelerated and mainstream classes who grew up in Norway also came from bi- or multilingual families, either Sami or with an immigrant background, and nearly all of the students had started a third language subject at school, such as French, German, or Spanish. A wide variety of languages were thus represented in all three classes, involving both elite and minoritized multilingualism (see Ortega 2019). Some students' linguistic repertoires will be described in the findings as illustrative examples, but in some cases details that are not considered analytically necessary are withheld in order to provide the students with greater internal confidentiality. The teacher of the three English classes, Lars ${ }^{1}$, identified Norwegian as his first language. He was also fluent in English and had studied German at school.

\section{Design and methods}

Based on the research gaps identified above, the present study addresses the following research questions:

1. In what ways is translanguaging marked in the teaching and learning of English as an additional language for linguistically majoritized or minoritized students?

2. How does such marking apply across an accelerated, a mainstream, and a sheltered English class?

In order to answer these research questions, the study employs a comparative design across three classes with different student characteristics, taught by the same teacher, as described in greater detail above.

The study uses linguistic ethnography as an overarching methodological and interpretive approach that seeks to uncover participant perspectives and contextualize these in larger societal discourses and structures (Copland and Creese 2015). Linguistic ethnography operates on two basic assumptions: that contexts of

1 All participant names are pseudonyms. 
communication need to be investigated rather than assumed; and that the internal organization of verbal and semiotic data provide cues to the significance and positioning of such data (Rampton 2007, p. 585). These assumptions translate methodologically into a combination of open ethnographically inspired investigations and fine-grained linguistic analysis, generally involving participant observation (Copland and Creese 2015; Rampton 2007). Since a participant observer by definition is bound to influence the context in some way, validity is sought not by avoiding influence on the setting outright but rather through reflexivity and accounting for one's role in producing the data (Copland and Creese 2015). Some of the positionalities that likely lent me legitimacy and authority in my interactions with the participating teacher and students included my being a former English teacher and current English teacher educator, usually perceived as a white bilingual "native speaker" of both English and Norwegian. In negotiating relationships with students, I at times also foregrounded my experience of moving internationally as an adolescent and being a learner and user of Arabic and French.

As part of a larger project, I conducted participant observation at the school from August to December 2017, about 2-4 days per week. I wrote field notes, videorecorded most classroom instruction, and made selected video or audio recordings of student interactions. Students who chose to do so also made screen recordings on their laptops while working on writing tasks. In addition, I collected student notes and texts and teacher feedback, took photographs of select classroom artifacts, and guided students in creating language portraits (Busch 2012), which they also described in written or audio-recorded narratives. Based on the aforementioned data sources, I conducted stimulated recall interviews (Dempsey 2010) with the teacher and 17 focus students, as well as semi-structured interviews with five additional students for contextualizing information. The focus students were chosen to represent all three classes and a variety of linguistic backgrounds in each class. Methods, data sources, and participants are summarized in Table 2.

As illustrated in Table 2, the number of participants for each type of data varied significantly. This resulted from a combination of students' choices concerning how to participate (e.g., reservation from video or screen recording), turnover in the classes (e.g., joining after language portrait creation), and researcher capacity (e.g., number of student interviews). Given the large quantity of recorded data, only the researcher voice memo and recordings of interviews, student interactions, and three language portrait narratives that were audio-recorded rather than written were transcribed in their entirety. The transcripts and field notes were uploaded to the data analysis software NVivo and subjected to a two-stage coding process. Content logs were created for the recordings of student screens and classroom instruction, which were used for subsequent triangulation and 
Table 2: Data sources.

\begin{tabular}{|c|c|c|c|}
\hline Method & Data & Participants & Quantity \\
\hline \multirow[t]{9}{*}{ Observation } & Field notes & $\begin{array}{l}\text { Teacher }(N=1) \\
\text { Students }(N=54)\end{array}$ & 132,468 words \\
\hline & Voice memo (field note) & Researcher & $6 \min 13 s$ \\
\hline & Video of classroom & Teacher $(N=1)$ & Angle $1: 24 \mathrm{~h} 30 \mathrm{~min} 16 \mathrm{~s}$ \\
\hline & instruction & Students $(n=45)$ & Angle 2: $19 \mathrm{~h} 33 \min 32 \mathrm{~s}$ \\
\hline & Video of student interactions & Students $(n=11)$ & $2 \mathrm{~h} 19 \min 00 \mathrm{~s}$ \\
\hline & Audio of student interactions & Students $(n=7)$ & $1 \mathrm{~h} 55 \mathrm{~min} 24 \mathrm{~s}$ \\
\hline & $\begin{array}{l}\text { Audio of teacher } \\
\text { feedback conferences }\end{array}$ & $\begin{array}{l}\text { Teacher }(N=1) \\
\text { Students }(n=3)\end{array}$ & $13 \min 30 \mathrm{~s}$ \\
\hline & Screen recordings & Students $(n=20)$ & $46 \mathrm{~h} 47 \min 24 \mathrm{~s}$ \\
\hline & Photographs & Students $(n=7)$ & 26 photographs \\
\hline Document & Students texts & Students $(n=48)$ & 151 texts \\
\hline \multirow[t]{2}{*}{ collection } & Teacher feedback (written) & $\begin{array}{l}\text { Teacher }(N=1) \\
\text { Students }(n=37)\end{array}$ & 44 texts \\
\hline & $\begin{array}{l}\text { Language portraits, } \\
\text { with narrative descriptions }\end{array}$ & Students $(n=46)$ & 46 portraits \\
\hline \multirow[t]{3}{*}{ Interview } & Audio recordings & Students $(n=22)^{\mathrm{a}}$ & $10 \mathrm{~h} 54 \mathrm{~min} 01 \mathrm{~s}$ \\
\hline & & Teacher $(N=1)$ & $1 \mathrm{~h} 19 \min 05 \mathrm{~s}$ \\
\hline & Video recordings & Student $(n=1)^{\mathrm{a}}$ & $3 \min 21 \mathrm{~s}$ \\
\hline
\end{tabular}

${ }^{a}$ Note. Of the 22 students interviewed, one also consented to video recording.

identification of focal episodes for interaction analysis (Jordan and Henderson 1995). The analytical process is illustrated in Figure 1.

As illustrated in Figure 1, after data preparation, the first round of coding involved mostly inductive application of eclectic codes, including descriptive, emotion, in vivo, process, value and versus codes (Saldaña 2015). The second round, consisting of focused coding (Saldaña 2015), can be described as abductive, drawing on theoretical constructs to anchor emerging themes (Alvesson and Sköldberg 2017; Copland and Creese 2015). At this stage, I also narrowed my analytical focus to five themes (see Figure 1, "Focused coding"). By reviewing these themes across the data sources, I then identified patterns of translanguaging and "rare events" (Erickson 1986, p. 149), which led to formulating preliminary analytical assertions and identifying illustrative focal episodes. I transcribed and conducted interaction analysis of focal episodes in the recorded classroom data and reviewed the documentary data (photographs, texts, language portraits), in order to verify or nuance the preliminary assertions (Copland and Creese 2015; Erickson 1986; Jordan and Henderson 1995). A guiding principle was to formulate, test, and refine analytical assertions such that they could account for both frequent and rare events in the data (Erickson 1986, p. 149). 


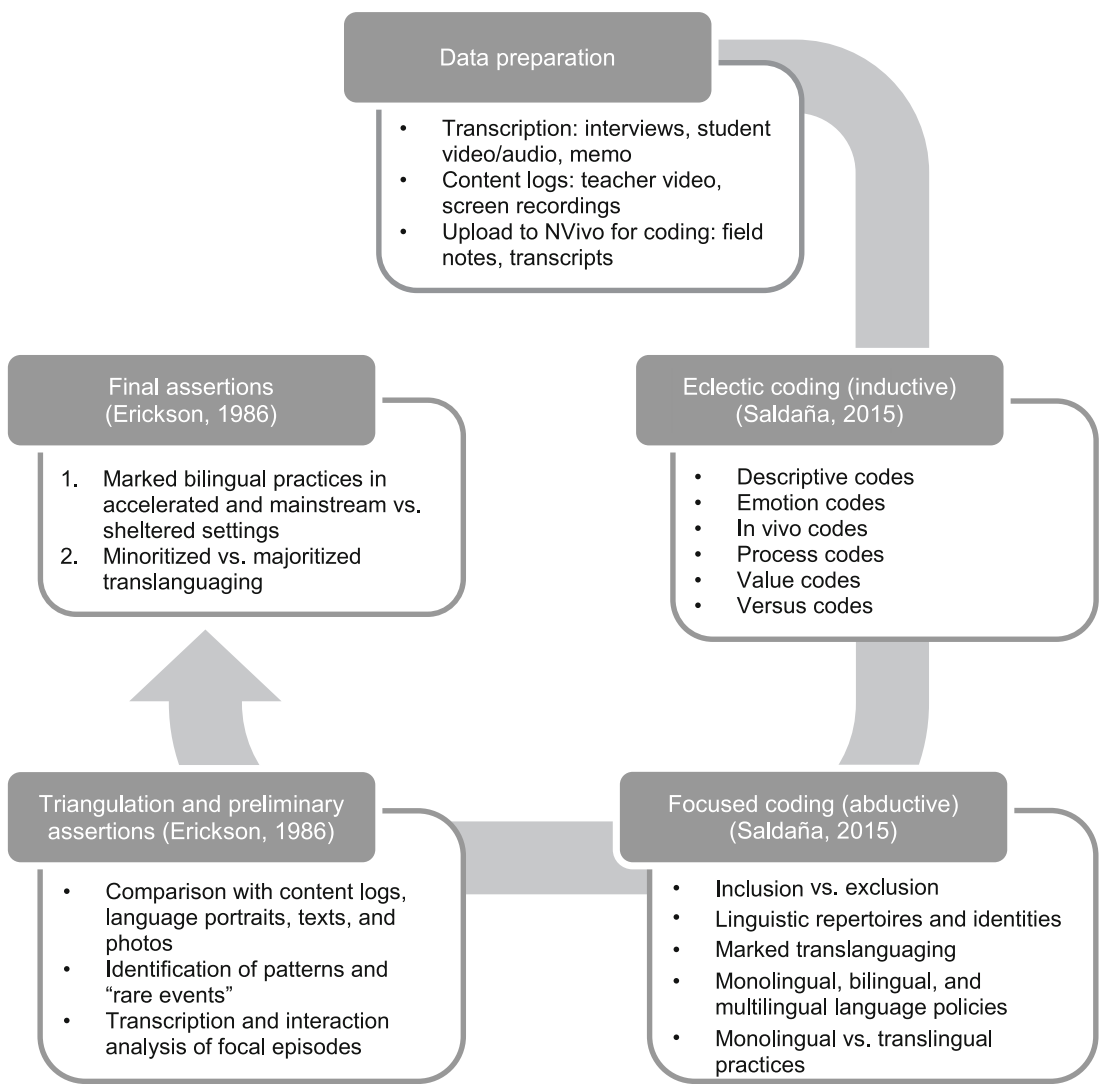

Figure 1: Analytical process.

\section{Findings}

Through the analytical process, I arrived at two patterns of marking translanguaging: the more frequent marking of Norwegian-English bilingual practices in accelerated and mainstream settings compared to the sheltered classroom; and the relatively consistent marking of translanguaging that drew on minoritized languages across all settings. The data extracts presented below were chosen because they are representative of these patterns or provide rare counterpoints that help to clarify the patterns. 


\subsection{Marked bilingual practices in accelerated, mainstream, and sheltered settings}

Translanguaging was overall less common and more marked in the accelerated class compared to the mainstream class, and in these two classes than in the sheltered class. The differences in practices could be seen both in Lars's regulation of language use and in how students themselves chose to draw on their linguistic repertoires in individual and peer work. This pattern of variation across the three classes indexed a discourse that juxtaposed a desired monolingual English performance with translanguaging as needed for task accomplishment (Brevik and Rindal 2020; Rosiers et al. 2018). This monolingual expectation was upheld most strictly in the accelerated class, where all of the students were presumed to be quite fluent in English. In contrast, the mainstream class included a wider range of proficiency levels and experiences with English, and students in the sheltered class had all previously struggled with the subject. However, English was not usually juxtaposed with translanguaging per se, but rather with a more specific form of translanguaging: bilingual English-Norwegian practices. Marking of translanguaging in contrast to a desired English performance thus constituted a specific kind of translanguaging, one that drew on majoritized languages enshrined in the curriculum and shared by the teacher and students (see "elite bilingualism" in Ortega 2019, p. 27), which I call marked bilingual practices.

Accordingly, there were numerous instances in the accelerated and mainstream classes in which the teacher reminded students to speak English or not to speak Norwegian. The following excerpt illustrates the marking of bilingual practices in a teacher-fronted discussion in the accelerated class. The excerpt begins with a student called Tom giving an elaborated response to a question from Lars about literary characters.

Excerpt 1: "Don’t use a single Norwegian word" (video, accelerated class)².

1 Tom: and she adds something to the story because you kind of get a, frampek

$2 \quad<$ foreshadowing $>$ to $(\mathrm{xxx})$

3 Lars: yes, frampek <foreshadowing $>$, that's a very good word, these are

4 words you guys should be using in the conversation with me, but not in

$5 \quad$ Norwegian, ok?

6 Tom: yeah

2 Unless otherwise noted, translations are from Norwegian. 


\section{Excerpt 1: Continued}

7 Lars: ((chuckles)) don't use a single Norwegian word in your

8 [conversations, uh, with me, but the word,

$9 \quad[(($ writes "frampek" on the board))

10 frampek <foreshadowing $>$, what do you do by the way if you have a

11 Norwegian word in your head and you're struggling and you want to

12 get it out? in English, how do you do that? ((waits)) yes

13 Sofie: um, you could, maybe explain the word

14 Lars: yes, you can try to explain, the concept, right? try to say it with, other English words, you'll be able to do that, or if you're in dire straits and you absolutely need help, you can ask me, hey Lars is it ok if I ask for a Norwegian word here, I need help, ((short chuckle)) alright? perfectly fine, just don't go off before I let you, speaking Norwegian, ok? you never know for an exam, for instance, what a sensor ['scnsəx] <examiner>, might think of that, ok? so just stop stop any Norwegian you guys might have thought of [so, frampek < foreshadowing > in, Norwegian, what- in English I mean, what do you guys think?

25 Fredrik: foreshadowing

26 Lars: foreshadowing, [exactly, so not that [but this, fore-shadowing, yes, foreshadowing, foreshadowing, [((crosses out "frampek")) et frampek <a foreshadowing>, exactly, you get a [hint, of something that is about to happen, right?

$[(($ raises arm $))$

you get little, um, [drips of something about to happen $[($ taps air with fingers))

In Excerpt 1, Tom used the Norwegian literary term frampek ("foreshadowing") to contribute an idea to a class discussion, a shift that he subtly marked with a pause (line 1). In response, Lars affirmed the value of using a precise literary concept but also marked switching to Norwegian as a deviation (lines 3-5). Lars's comment was more specifically framed in the context of "the conversation with me" (line 4), which likely referred to an oral assessment the class was anticipating, literally called a "subject conversation" (fagsamtale) in Norwegian, rather than private conversations with him in general, where he regularly accepted that students drew 
on Norwegian. Indeed, rather than moving on with the class discussion, Lars used Tom's recourse to a Norwegian term as an opportunity to elaborate on strategies for managing the monolingual expectation in assessment situations, including circumlocution (line 14-15) and asking for permission to draw on Norwegian "if you're in dire straits" (line 15). Indeed, translanguaging is often deemed problematic in language teaching based on its widespread unacceptability in language assessments (Schissel et al. 2018).

It is nonetheless important to note that Lars himself subtly translanguaged in unmarked ways in Excerpt 1. Lars integrated two terms into his English performance that were locally recognizable in reference to the Norwegian school system but might not carry the same meaning to English speakers elsewhere, namely "conversation" (lines 4,8 ) to refer to oral assessment and "sensor" ("examiner"), where he pronounced the Norwegian word for an examiner with American English phonology, ['scnsəx] (line 19). Thus, such seemingly monolingual speech can also be seen as translingual (Canagarajah 2013). Lars also drew on his bodily and spatial resources to communicate effectively with his students, crossing out "frampek" before replacing it with "foreshadowing", accompanied respectively by the deictics "that" and "this" (lines 26-29) and tapping his fingers in the air to convey the meaning of “drips” (lines 33-34). Such uses of embodied and spatial resources are increasingly emphasized as elements of translanguaging (Canagarajah 2018; Li Wei 2018).

In contrast to his frequent marking of bilingual practices in the mainstream classes, especially in teacher-fronted discussions, Lars permitted students to draw extensively on Norwegian without comment in the sheltered class and in interactions with students in the mainstream class whom he considered to have greater difficulty with English. In the sheltered class, he even occasionally encouraged students to use Norwegian, as in the following excerpt, where Lars and his students discussed a polemical writing prompt to which he had asked the students to respond: "Human rights do not matter."

Excerpt 2: Bilingual practices in the sheltered class (video, sheltered class).

1 Rachelle: er det noen imot <is there anyone against $>$ the human rights?

2 Lars: hm?

3 Rachelle: er det noen- finnes det noen personer som er imot <is there anyone-are there any people who are against $>$ the human rights?

5 Lars: um, yes, yeah, yeah, there are, um, but that's not the questionthe- the claim though, the claim is [human rights do not matter, right? [do they matter, or [do they not matter, altså betyr de noe? [((underlining on the board)) [((hands together)) [((hands apart)) 
Excerpt 2: Continued

10

11

12

13 Lars:

14

15

16

har de noen effekt? har de noen virkning? spiller det noen rolle om vi har dem? <that is do they count? do they have any effect? do they have any impact? does it matter if we have them?> [...]

ok, but- but play off each other now, I want you guys to talk about this alright, to get some ideas, and you may speak in Norwegian then if you feel more comfortable doing that, to prepare yourself for the writing, ok?

In Excerpt 2, Rachelle challenged Lars on the premise of the writing prompt (line 1). As a refugee from the war in Syria, Rachelle might have found this proposition especially troubling. Lars signaled for Rachelle to repeat the question (line 2), and rather than interpreting this as a request to reformulate the question in English, she posed her question in different terms, still drawing on both Norwegian and English (lines 3-4). In contrast with his response to Tom (see Excerpt 1), here Lars did not mark Rachelle's translanguaging, responding instead to the content of her question (lines 5-11). In fact, he himself translanguaged to provide an elaborated response, drawing on English (lines 5-7) and Norwegian (line 8-11), as well as bodily and spatial resources (see Canagarajah 2018). Specifically, he used his hand to underline text on the board and communicated a contrast through gesturing, moving his hands together and apart (line 8-9). Finally, before releasing the students to work together on generating ideas for writing, he proactively reminded them that they could speak Norwegian if they would feel more comfortable doing so (lines 14-16). To the extent that translanguaging was marked, it was to remind the students that they did not need to work monolingually, though without reference to any languages beyond English or Norwegian.

The variations in Lars's regulation of language use pointed to a principle of translanguaging as needed to support understanding and engagement in the task, which seemed less necessary to him among students with higher proficiency in English. Lars explained in his interview that he saw Norwegian as being useful for clarifying and consolidating English terms in all classes, but especially for students with lower English proficiency. A second principle also favored EnglishNorwegian bilingual practices in the sheltered class: the broader institutional emphasis on developing immigrant students' Norwegian proficiency (see Beiler 2020; Burner and Carlsen 2019; Krulatz and Torgersen 2016). Lars explained that "especially in [the sheltered class] I use Norwegian much more, because I also consider it important that they learn Norwegian better too, so there I use Norwegian, not exactly interchangeably with English, but more Norwegian, maybe 
repeat a question in Norwegian" (interview, my translation). These statements reveal at least two salient discourses informing unmarked bilingual practices. First, Lars conceived of language learning as bidirectional rather than being in competition; thus the primary language of schooling (Norwegian) could be used to support English learning, while English lessons could simultaneously support students' developing Norwegian proficiency (see Beiler 2020; Cenoz and Gorter 2017). Second, a discourse of needing to develop majority language proficiency followed "minority language speakers" across school subjects. Even in other language subjects such as English, drawing on Norwegian became institutionally desirable for these particular students because it indexed integration into majority language practices (see Beiler 2020; Burner and Carlsen 2019; Krulatz and Torgersen 2016). For linguistically majoritized students, drawing on Norwegian in English class was often permissible but not desirable in the same way.

With respect to students' language ideologies and practices in their spontaneous interactions and individual work, great variations could be observed among students, especially in the accelerated and mainstream classes. Some students expressed more consciously monolingual orientations to their writing processes (see Canagarajah 2013) and attempted to work in English only, while others drew more extensively on their full linguistic repertoires to read, plan, or translate for writing (see also Beiler 2020; Beiler and Dewilde 2020). Still, overall, the students in the sheltered class drew more consistently on resources other than English. This may be unsurprising given the fact that their placement in the class reflected a lower achievement level in English. One of these students, Sara, explained why she would draw on Norwegian:

Sometimes I speak Norwegian when I'm unsure, or when I don't know how I should say it, so I know that I can say it in Norwegian, so it's a little easier for me, or I feel much better that I know that I have that possibility, instead of not having it and being quiet for example, right? (interview, my translation)

To Sara, the alternative to speaking Norwegian would sometimes be silence. Having this possibility encouraged her participation, even as she also stated that she liked the language exposure she received by having most of the class conducted in English, unlike at her earlier school in Poland. These opinions were also voiced by many students in all three classes, that they appreciated both that Lars spoke so much English and that they were not held to a strictly monolingual standard (see also Brevik and Rindal 2020). Sara and other multilingual students would also draw on resources other than English or Norwegian, especially in their private work. However, patterns of such minoritized translanguaging largely indexed a different discourse than marked bilingual practices, as I present in the next section. 


\subsection{Minoritized translanguaging: Marked across instructional settings}

As presented in the previous section, marked bilingual practices indexed a desired monoglossic English performance, but the extent to which bilingual practices were marked varied by instructional setting and students' perceived readiness to perform monolingually in English. A second pattern applied more similarly across all three instructional settings, whereby translanguaging that drew on minoritized languages was less visible but more consistently marked when it became visible to others. Such minoritized translanguaging was more inherently marked in relation to societal language hierarchies and raciolinguistic ideologies (Daugaard and Laursen 2012; Flores and Rosa 2015). Indeed, constraints on minoritized translanguaging indexed a discourse of inclusion through conformity to majority linguistic practices (see Piller and Takahashi 2011). Accordingly, students' minoritized language resources were primarily made visible to others outside of curricular activities, in occasional language play or personal conversations (cf. Rosiers et al. 2018). Even in the sheltered class, where all of the students were recent immigrants, students reproduced societal discourses defining minority language communication as antisocial (e.g., Flognfeldt 2018; Krulatz and Torgersen 2016). In the following field note excerpt, two students reacted negatively to a brief exchange in Arabic by Rachelle and another classmate from Syria.

Excerpt 3. "They are talking behind our backs" (field note, sheltered class,)

The teacher recaps their discussion thus far: "This is for the very few, not everyone, that is the problem of the American Dream." Rachelle summarizes the teacher's point about the American Dream for Lamis in Arabic. At this point, two classmates comment on the fact that the girls are speaking Arabic. One of them says, "De baksnakker oss." $<$ They are talking behind our backs.> Rachelle appeals to me, that I understand what they are saying. I confirm that she is helping Lamis with the task.

In this field note, two classmates indicated suspicion of Lamis and Rachelle's speaking in Arabic, even though the students were all friends. Unlike the taskrelated marking of Norwegian, this kind of language policing by peers marked minoritized language use as inherently suspicious and antisocial (see Flognfeldt 2018; Krulatz and Torgersen 2016; Mary and Young 2017; Piller and Takahashi 2011). These classmates, who were themselves minoritized speakers at school, can be seen as enacting the position of the white "ethnic Norwegian" listening subject by defining minoritized languages as inappropriate in class (see Flores and Rosa 2015; Rosa and Flores 2017). In response, Rachelle appealed to an authority figure, me, the researcher who could understand and legitimize their departure from 
majoritized languages as being task-related. In subsequent interviews, all four students acknowledged that shared minoritized languages could provide important learning support, as practiced by Rachelle and Lamis in Excerpt 3 (e.g., Duarte 2019; García and Kleyn 2016). However, they also described it as exclusionary to speak a language that not everyone present could understand (see also Flognfeldt 2018; Krulatz and Torgersen 2016; Piller and Takahashi 2011). Nearly all of the students in the sheltered class described self-policing for this reason, avoiding minoritized translanguaging so as not to exclude or be seen as excluding others who would not be able to understand. Sara even reported that she had started messaging a Polish classmate in Norwegian because she had gotten so used to avoiding Polish around others. While all of these students justified their choices with reference to personal courtesy rather than explicitly assimilationist or raciolinguistic ideologies (Flores and Rosa 2015; Piller and Takahashi 2011), they nonetheless oriented to an implied listening subject who would normatively expect only Norwegian and English. Importantly, Lars did not question his students' motives for speaking Arabic in this instance or otherwise.

Nonetheless, Lars rarely drew on any languages beyond English or Norwegian in an explicit manner, with the exception of one instance of eliciting a translation in Dutch in the mainstream class. In this case, a student who had recently immigrated from the Netherlands was unable to come up with a word in either English or Norwegian (see Excerpt 4).

Excerpt 4: Lars elicits a Dutch word (video, mainstream class).

1 Lars: yes?

2 Bob: it's not like a choice to have like, the (debt) ${ }^{1}$, something

3 Lars: chose to have a?

4 Bob: uh, I don't know the English word, uh

5 Lars: do you know the Norwegian one?

6 Bob: uh, no

7 Lars: do you know the Dutch one? ((chuckles))

8 Bob: uh, schuld <D. debt>

9 Lars: what's that?

10 Frida: gjeld, tror jeg det heter $<$ N. debt, I think it's called $>$

11 Lars: hm? oh debt, gjeld $<\mathrm{N}$. debt $>$, yes studiegjeld $<\mathrm{N}$. student debt $>$,

12 debt, debt, she is discussing debt, what was that in Dutch?

13 Bob: schuld $<$ D. debt $>$ 
Excerpt 4: Continued

14 Lars: sounds like school to me, so it wouldn't- it wouldn't help but ok, uh 15 yes, she is talking about student debt, absolutely, altså gjeld $<\mathrm{N}$. that is, debt>

Notes: $\mathrm{D}=$ translation from Dutch. $\mathrm{N}=$ translation from Norwegian. ${ }^{1}$ Pronounced [dapt].

In Excerpt 4, Lars was initially unable to understand Bob's non-standard pronunciation of the word "debt" (lines 2-3), to which Bob responded that he did not know the English word in question (line 4). Lars then elicited the word in Dutch when Bob did not know the word in Norwegian. Lars's comment in line 14 suggests that he was hoping for a recognizable cognate, an intention he confirmed in his interview. Like the other languages in his repertoire (Norwegian, English, German), Dutch is a Germanic language, and recognizing cognates is a wellestablished strategy for multilingual transfer (Cenoz and Gorter 2017). Since he could not understand the Dutch word, he deemed the strategy unhelpful (line 14). Instead, Bob's Dutch-speaking classmate Frida was able to interpret for him (line 10). As with students' use of Arabic in Excerpt 3, recourse to a language other than English or Norwegian required an expansion in the sources of expertise in the classroom (see García and Kleyn 2016; Mary and Young 2017; Rosiers et al. 2018). However, unlike Arabic in Excerpt 3, Dutch was invited officially from the front of the room, presented openly by students, and received without negative comment by classmates, thus seeming to escape the stigmatization and raciolinguistic policing tied to Arabic.

Indeed, Lars expressed wariness of pointing out students' minoritized language resources too explicitly in the mainstream classes out of a fear of stigmatizing students (see Excerpt 5).

Excerpt 5: "It has to be clarified beforehand" (interview, my translation).

1 Interviewer: in addition to the newly arrived students, do you think that

2

3

4 Lars:

5

6

7

8 your students' multilingualism is something you draw on in any other way in English teaching?

no, not very much actually, unfortunately not, because it requires a fair bit of knowledge about- on my- on my part, about both their culture and about the language, knowledge that I don't have, I feel, before I start with like- kind of superficial trivial comments, what- in in the classroom, so so I 
Excerpt 5: Continued

9

10

11

12

13

14

15

16

17

18

19

20

would rather have a little more knowledge about- more than what I can use it for, uh more than just making, kind of- kind of silly out of it, what is the word for coffee in Russian, for example [...] but it must, absolutely be clarified beforehand with the students in question [...] but it isn't something I can just on a whim ask questions about in the classroom, it has to be clarified beforehand, I think at least, it may depend on the person, but I would at least have clarified it beforehand, but it is possible to make them a resource, but everything depends on, that student, if they think it's OK, but absolutely, there is a resource there, but will it be stigmatizing? when when they present it, I really don't know

In this excerpt, Lars cited two reasons for not making more explicit references to his students' multilingualism. On the one hand, he felt that he needed more knowledge in order to draw on their multilingual repertoires in a substantive rather than trivial manner (lines 4-11). This may be one reason that he once elicited a Dutch word, which he hoped to recognize as a cognate (see Excerpt 4), whereas he did not similarly elicit terms in languages that were less familiar to him. On the other hand, he expressed a fear of students feeling stigmatized, signaled in the thrice-repeated concern with clarifying beforehand whether students would feel comfortable having their multilingualism pointed out (lines 12-16). Here Lars implicitly refers to a minoritized form of multilingualism, which has the potential to confer stigma (line 19) rather than prestige (see Ortega 2019; Piller and Takahashi 2011), or to students who are stigmatized rather than celebrated for their multilingualism because of their racialized position (Flores and Rosa 2015). In this example, minoritized multilingualism is exemplified by Russian, which like Dutch indexes white Europeanness, but in Norway also indexes xenophobic discourses about Eastern European working class labor migration, thus potentially marking students as a racialized Other (Dowling, 2017; Rosa and Flores 2017). Accordingly, minoritized multilingualism was inherently marked (Daugaard and Laursen 2012), unlike the English-Norwegian bilingualism that was merely situationally regulated. In practice, Lars's concern appeared to apply somewhat more weakly to the sheltered class, where all of the students were immigrants who were racialized to a greater or lesser extent, such that minoritized multilingualism was somewhat less marked.

In the mainstream and accelerated classes, which were in fact also very linguistically diverse, students' multilingualism was almost never topicalized or used in visible ways. It is important to note that all three classes generally seemed 
characterized by a comfortable classroom atmosphere and good relationships among the students and teacher; especially students in the sheltered and accelerated classes commented to this effect (cf. Allard 2017). Thus, the reasons for avoidance of minoritized translanguaging in the mainstream and accelerated classes are likely to be found outside of the immediate classroom setting, perhaps most obviously in linguistically minoritized students' earlier experiences of Norwegian "regimes of hearing" (Connor 2019, p. 56) in education. Indeed, only Halima could vaguely recall having been previously invited to use a minoritized language at school-in her case, Urdu, when she was enrolled in transitional mother tongue classes in early elementary school. A few students described more direct suppression, such as Sofie and Cece, who related that their parents were told to speak Norwegian to them rather than Sami and Farsi, respectively, when they entered preschool. Cece continued to act on her parents' advice not to speak Farsi outside of the home, lest others "look down on her" (field note), while Sofie reported that she had gradually developed more pride and willingness to have her family visibly identified as Sami, for instance no longer becoming upset with her parents for wearing the Sami kofte on Norway's national holiday. However, Sofie thought that such early experiences had contributed to her decision not to take Sami language distance education, to which she was legally entitled.

Only one student in these classes explicitly chose to translanguage despite negative reactions from classmates at times. Whereas students in the sheltered class felt the need to self-police and justify their occasional translanguaging, Shirin, a student in the accelerated class, asserted translanguaging as an aspect of her identity and way of being (Canagarajah 2013; Creese and Blackledge 2015). In describing her language portrait, she wrote,

Sometimes I am talking to someone and I realize that I have been speaking Kurdish for two minutes to someone who doesn't know the language at all, but I would not have it any other way, knowing and being familiar with many languages makes me feel closer to the world. (written narrative, my translation)

While Shirin acknowledged that translanguaging could entail misunderstandings, she positioned a translingual identity as desirable and asserted her right to base her interactions on her own positionality, without suppressing this for the sake of social harmony (see Canagarajah, 2013). Indeed, on her language portrait, Shirin represented Kurdish as very important to her, but the overall impression is of a student who identifies strongly as multilingual (see Figure 2).

In Figure 2, Shirin has assigned a different color to each language or variety, such as Sorani or Hawleri ${ }^{3}$ Kurdish ("Kurdi"). She uses hearts to encompass bits

3 From Hawler, the Kurdish name for Erbil. 


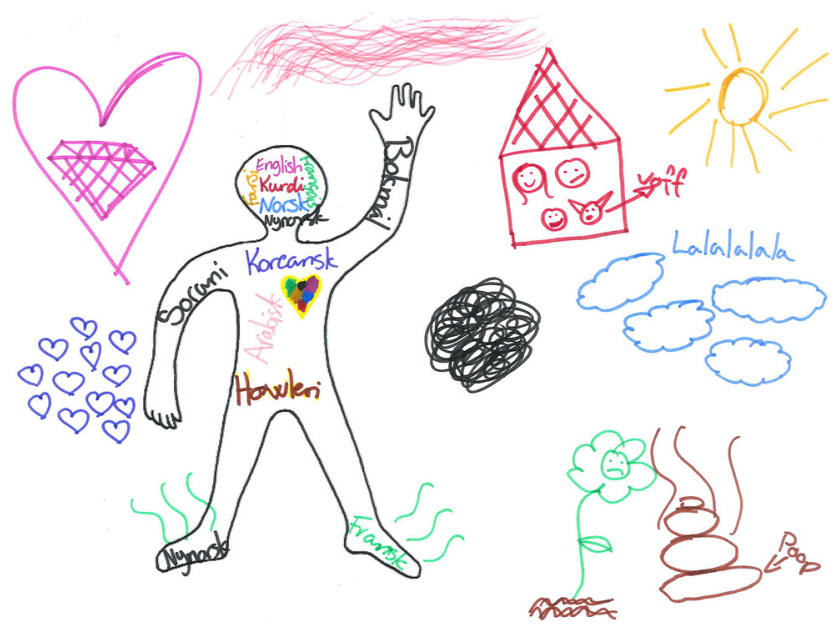

Figure 2: Shirin's language portrait.

and pieces of many languages, both those she knows quite well, like Norwegian, Kurdish, and English, and those she would like to know more of, like Korean. She also represents languages and varieties she considers out of reach ("Arabisk," "Arabic") or dislikes ("Fransk," "French," and "Nynorsk," "New Norwegian"). Shirin's representation of her linguistic repertoire destabilizes linear notions of first and second languages, as well as hierarchies between majoritized and minoritized languages (Seltzer 2019). Many other students in all three classes represented a complex multilingual repertoire in similarly vivid terms, but Shirin stood out for asserting her right to make language choices based on her identity and to reject others' language policing and racialization (see Excerpt 6).

Excerpt 6: “As long as I have someone who understands my language, I speak it” (interview, my translation).

1 Interviewer: what you're saying about using Kurdish at school [...] it

4 Shirin:

5 Interviewer:

7 Shirin: sounds like you think that it's- or like you have experienced that someone reacts negatively to it? $\mathrm{mm}$ mm definitely

does that affect at all how and when and where you choose to speak Kurdish, [or not speak Kurdish?

[no, no, I mean, as long as I have someone who understands my language, I speak it, because, it's- it has happened quite often that I'm speaking Kurdish and then a student comes over and just, you're in Norway so act like a Northerner ${ }^{1}$ 
Excerpt 6: Continued

11

13 Interviewer:

14 Shirin:

15

16

17

18

19

20 Interviewer:

21

22 Shirin:

23

24

25

26

27

28

29

30 and like, or however you say it, a Norwegian it's called, sorry, wow $^{2}$, I did get a good grade in Norwegian, no ((laughs)) I don't doubt that yeah so, I feel, Norwegian is like, Norwegian culture is just as much me as Kurdish culture but like it becomes pretty sad for me, it's so strange, but I get so sad when I don't get to speak Kurdish for several hours, and now our school has become mobile-free, so I can't call my mom when I miss speaking Kurdish [...]

yeah, so you do it anyway, even if, like, the fact that someone has come and said that to you, that's pretty= =sad, I know, yeah, I got really mad then, but my mom and dad taught me always not to react negatively when someone says things like that, because then it just proves it- because, because many think for example, people who are from abroad are a little like, wild quote non-quote, right, so like, it's been very often that when I have gotten quite mean comments, and I feel like they expect me to react wild, so I have like just stayed calm and so, so that they like, so I can try to shatter the picture they have of, quote non-quote, foreigners

Notes: ${ }^{1}$ She first uses the word for a person from Northern Norway, nordlending, and then self-corrects to the generic national demonym, nordmann.

${ }^{2}$ The underlined words are original, not translated.

In Excerpt 6, Shirin described racialized policing of her speaking Kurdish at school, in which other students would frame Kurdish as incompatible with Norwegianness (lines 8-11). Shirin rejected this raciolinguistic ideology, pointing out that she felt just as Norwegian as Kurdish and that there was no incompatibility in this fact (line 14-15). The emotional importance to her of using Kurdish weighed more strongly in her language choices than others' raciolinguistic policing (lines 1-8, 15-17). However, she did appear to feel constrained by raciolinguistic ideologies in some ways, needing to carefully manage her reactions to racist accusations, so as not to confirm the expectation that foreigners act "wild" (lines 25-30). The discursive power of these descriptors was emphasized by Shirin's use of "quote non-quote [unquote]" to frame both "wild" and "foreigners" (lines 26, 30) as circulating ideological categories. Furthermore, she defended a slip of the tongue with 
reference to receiving a good grade in Norwegian (lines 12), thus preempting a possible negative judgment of her legitimacy as a speaker of Norwegian in the interview.

In sum, Shirin experienced her translanguaging and her translingual identity as negatively marked in school, but she refused to restrict her linguistic repertoire accordingly. Compared to the students in the sheltered class, she may have felt more secure in resisting raciolinguistic policing, based on her position as a fluent speaker of Norwegian and advanced user of English who had grown up in Norway. However, without greater access to students' lives outside of school, it is difficult to know which personal or social factors allowed Shirin to resist linguistic stigmatization and racialization more overtly than many of her peers who were in a similar position to her at school (see Canagarajah, 2013). Nonetheless, her experience reminds us that discourses of markedness are neither absolute nor nonnegotiable (Meeuwis and Blommaert 1994).

\section{Discussion and conclusion}

In this study, I found that translanguaging occurred in opposition to two largely separate discourses: a discourse of monoglossic English performance and a discourse of inclusion through conformity to majority linguistic practices. This first discourse constituted English-Norwegian bilingual practices as its marked opposite, while the second discourse marked minoritized translanguaging as an obstacle to inclusion, thus as qualitatively different from majoritized EnglishNorwegian bilingual practices. The first discourse applied differently across accelerated, mainstream, and sheltered instructional settings, such that bilingual practices were least marked in the sheltered class, based on students' greater perceived need to construct meaning through translanguaging, as well as the desirability of increasing their Norwegian proficiency. In contrast, minoritized translanguaging was more similarly marked in all three classes, indexing hegemonic national language ideologies more so than ideologies of language learning.

This study therefore suggests a need to disambiguate among various forms of translanguaging in the classroom, based on which discourses or ideologies they index. In many previous studies, translanguaging has been contrasted with a broadly monolingual or monoglossic ideology that stigmatizes bi- and multilingual students' language practices (e.g., Creese and Blackledge 2015; García and Kleyn 2016; Mary and Young 2017). The current study suggests that there are at least two issues that potentially constrain translanguaging in language classrooms, which may overlap to a greater extent in some contexts than others: monoglossic ideologies of effective additional language learning and 
marginalization of certain speakers based on an ideology of national linguistic homogeneity, which may also mark minoritized speakers unequally based on their racialized position (Flores and Rosa 2015, 2019; Lindquist and Osler 2016). While these discourses may largely coincide in settings where minoritized language learners are learning a majority language as part of mainstreaming efforts (e.g., "English Language Development” in Leung and Valdés 2019, p. 351), in the current context these discourses had significantly different fields of application.

In the current study, only the national majority language Norwegian was seen as encroaching significantly upon English target language use. Thus the teacher's management of language use could most accurately be described in terms of regulating majoritized bilingual practices. This discourse certainly aligns with a monoglossic conception of languages as bounded and separate (García 2009; Ortega 2019; Piller and Takahashi 2011), not just on the part of individual teachers or students but also in the institutional formulation and assessment of English as a school subject. However, at a societal level, the unmarked prestigious alternative, indeed the curricular expectation, is to develop Norwegian-English bilingualism, ideally also extended to "elite" multilingualism (Ortega 2019, p. 34) with standard forms of prestigious and economically in-demand languages such as Spanish, German, or French, much as García and Otheguy (2020) describe officially sanctioned plurilingualism for linguistically majoritized white students in Europe. Thus, this discourse related to concerns about pedagogical effectiveness and student engagement, as seen in the teacher's shifting standards for how strongly to insist on a monoglossic English performance with students at various levels of English proficiency.

In contrast, the discourse of inclusion through conformity to majority linguistic practices was one that marked minoritized multilingualism as inherently undesirable in school (Daugaard and Laursen 2012), following racialized students regardless of instructional setting (Flores and Rosa 2015). The translanguaging that was constrained by this discourse, which I have called minoritized translanguaging, can be seen as the impetus for proposing translanguaging as a counter-hegemonic pedagogical approach (e.g., Creese and Blackledge 2015; García 2009; García and Li Wei 2014; García and Otheguy 2020; Hornberger and Link 2012; Makalela 2015). A barrier to creating the conditions for minoritized translanguaging in these classrooms proved to be a linguistically hegemonic norm of inclusion, where visible language use and policing oriented to the white "ethnic Norwegian" listening subject (Connor 2019; Flores and Rosa 2015; Piller and Takahashi 2011). Thus, the study suggests the analytical value of describing locally salient forms of translanguaging in conjunction with the specific discourses it challenges or transcends, as part of the language ecologies that influence translanguaging in various locations (Allard 2017; Hawkins and Mori 2018). This may 
help to address concerns about the conflation of linguistic hybridity with emancipatory agendas, both from those who have questioned the inherently counterhegemonic impact of translanguaging (Block 2018; Cenoz and Gorter 2017; Jaspers 2018) and those who have sought to clarify translanguaging as more than mere fluid language use (e.g., García and Otheguy 2020; Ortega 2019).

A practical implication of this study is to focus more on how students support or constrain translanguaging in education. Much previous research has emphasized the role of teacher attitudes and knowledge about translanguaging pedagogies (e.g., García and Kleyn 2016; Krulatz and Iversen 2019; Makalela 2015; Mary and Young 2017; Schissel et al. 2018), and indeed Lars indicated that such training might help him to draw on students' multilingual resources in more than a superficial manner. Given the significant role that peers played in policing minoritized translanguaging, this study brings attention to the need for not only teachers, but also students, to interrogate the language ideologies that push them to perceive majoritized language practices as appropriate in school and minoritized translanguaging-their own or others'-as antisocial, suspicious, or perhaps valuable only for communication within linguistically minoritized homes and social arenas (Alim 2007). Canagarajah (2013) argues that critical translingual pedagogies may encourage students to develop translingual dispositions in place of monolingual and monoglossic ideologies, including a tolerance for ambiguity, where more monolingually oriented classrooms might suppress the same potential. In addition, more research is needed to identify factors that allow some students, like Shirin, to resist raciolinguistic policing to a greater extent than peers who seemingly occupy a similar racialized or minoritized position at school (see also Canagarajah 2013).

However, efforts that focus only on classroom practice are likely to fall short of fundamentally reordering the hierarchies of whose translanguaging is negatively marked in school (Flores and Chaparro 2018). Flores et al. (2018) demonstrate that even bilingual teachers who have generally positive attitudes toward translanguaging may police their students' language in racialized ways out of a perceived responsibility to prepare their students for a racially and linguistically stratified world outside of school. Jaspers (2018) similarly argues for creating conditions that are favorable toward translanguaging by focusing not only on schools, but also on justice and access in public services and employment. Indeed, most students in the current study seemed to have adapted to the logic of the white “ethnic Norwegian" listening subject, which naturalized majoritized language use outside of the home, long before they joined their upper secondary English class. In this view, language education can only constitute one element of larger struggles for justice that also address structural frames such as racism, economic inequalities, and disparities in political representation (Block 2018; Flores et al. 2018; Flores and Rosa 2015; Jaspers 2018). Nonetheless, the language classroom might 
comprise one such arena, which has the potential to give students tools to participate in these larger democratic struggles by providing opportunities to critically examine hegemonic language ideologies (Alim 2007; Canagarajah 2013; Flores and Rosa 2015; García and Kano 2014; Seltzer 2019).

In conclusion, in providing empirical evidence of how translanguaging may operate differently in reference to different language resources and learners, I hope to have contributed to clarifying the dynamics of translanguaging in additional language learning for both linguistically minoritized and majoritized learners (Leung and Valdés 2019; Turner and Lin 2017). The study supports earlier claims that teachers and students can use translanguaging for teaching and learning in linguistically diverse classrooms (e.g., Duarte 2019; García and Kleyn 2016; Mary and Young 2017; Rosiers et al. 2018), while also suggesting that translanguaging can remain largely at the level of majoritized language use without challenging linguistic inequality more fundamentally. Translanguaging may indeed be transformative (cf. Jaspers 2018), but perhaps only to the extent that it challenges a hegemonic discourse that is in operation locally (see also Allard 2017) and connects to broader movements for social justice (Flores and Chaparro 2018; Flores et al. 2018). Attending more directly to the locally specific discourses and ideologies that translanguaging transcends may make it easier to compare the impact of translanguaging in different language learning contexts and sociolinguistic ecologies.

\section{Transcription conventions}

$\begin{array}{ll}- & \text { cut-off } \\ ? & \text { rising intonation } \\ , & \text { pause } \\ () & \text { unclear } \\ (()) & \text { explanation or extra-linguistic information } \\ {[\ldots]} & \text { ellipsis } \\ {[} & \text { overlap } \\ = & \text { latched speech } \\ <\text { italics }>\text { translation into English }\end{array}$

Acknowledgements: I would like to thank the students and teacher for participating in the study. I also wish to thank Associate Professors Lisbeth M. Brevik and Joke Dewilde and the other members of the SISCO research group at the University of Oslo for commenting on an earlier version of this article 


\section{References}

Alim, H. Samy, 2007. Critical hip-hop language pedagogies: Combat, consciousness, and the cultural politics of communication. Journal of Language, Identity \& Education 6(2), 161-176.

Allard, Elaine C. 2017. Re-examining teacher translanguaging: An ecological perspective. Bilingual Research Journal 40(2). 16-130.

Alvesson, Mats \& Kaj Sköldberg. 2017. Reflexive methodology: New vistas for qualitative research, 3rd edn. Los Angeles: SAGE.

Baynham, Mike \& Tong King Lee. 2019. Translation and translanguaging. New York: Routledge.

Beiler, Ingrid R., 2020. Negotiating multilingual resources in English writing instruction for recent immigrants to Norway. TESOL Quarterly 54(1), 5-29.

Beiler, Ingrid R., \& Dewilde, Joke, 2020. Translation as translingual writing practice in English as an additional language. Modern Language Journal. In press.

Block, David, 2018. The political economy of language education research (or the lack thereof): Nancy Fraser and the case of translanguaging David. Critical Inquiry in Language Studies 15(4), 237-257.

Brevik, Lisbeth M., \& Ulrikke Rindal. 2020. Language use in the classroom: Balancing target language exposure with the need for other languages. TESOL Quarterly 1-29. https://doi. org/10.1002/tesq.564.

Burner, Tony \& Christian Carlsen. 2019. Teacher qualifications, perceptions and practices concerning multilingualism at a school for newly arrived students in Norway. International Journal of Multilingualism 1-15. https://doi.org/10.1080/14790718.2019.1631317.

Busch, Brigitta. 2012. The linguistic repertoire revisited. Applied Linguistics 33(5). 503-523.

Canagarajah, Suresh. 2013. Translingual practice: Global Englishes and cosmopolitan relations. New York: Routledge. https://doi.org/10.4324/9780203073889.

Canagarajah, Suresh. 2018. Translingual practice as spatial repertoires: Expanding the paradigm beyond structuralist orientations. Applied Linguistics 39(1). 31-54.

Cenoz, Jasone \& Durk Gorter. 2017. Minority languages and sustainable translanguaging: Threat or opportunity? Journal of Multilingual and Multicultural Development 38(10). 901-912.

Connor, Janet E. 2019. Regimes of hearing: Norwegian qualia of quiet and noise as heard through a migrant classroom. Language and Communication 66. 55-66.

Copland, Fiona \& Angela Creese. 2015. Linguistic ethnography: Collecting, analysing and presenting data. London: SAGE.

Creese, Angela \& Adrian Blackledge. 2015. Translanguaging and identity in educational settings. Annual Review of Applied Linguistics 35. 20-35.

Daugaard, Line M., \& Helle Pia Laursen. 2012. Multilingual classrooms as sites of negotiations of language and literacy. In A. Pitkänen-Huhta \& L. Holm (eds.), Literacy practices in transition: Perspectives from the Nordic countries, 103-118. Bristol (UK): Multilingual Matters.

Dempsey, Nicholas P. 2010. Stimulated recall interviews in ethnography. Qualitative Sociology 33(3), 349-367.

Duarte, Joana. 2019. Translanguaging in mainstream education: A sociocultural approach. International Journal of Bilingual Education and Bilingualism 22(2). 150-164.

Dowling, Fiona. 2017. “'Rase' og etnisitet? Det kan ikke jeg si noe særlig om - her er det 'Blendahvitt”! [“'Race' and ethnicity? I can't say much about that - here, it’s all 'lily-white”!] Norsk pedagogisk tidsskrift 101(3). 252-256. 
Erickson, Frederick. 1986. Qualitative methods in research on teaching. In M. Wittrock (ed.), Handbook of research on teaching, 3rd ed. 119-161. New York: Macmillan.

Flognfeldt, Mona E., 2018. Teaching and learning English in multilingual early primary classrooms. In: Palm, Kirsten, Michaelsen, Eva (Eds.), Den viktige begynneropplæringen: En forskningsbasert tilnærming [The crucial early literacy instruction: A research-based approach]. Scandinavian University Press, Oslo, pp. 229-248.

Flores, Nelson \& Sofia Chaparro. 2018. What counts as language education policy? Developing a materialist anti-racist approach to language activism. Language Policy 17(3). 365-384.

Flores, Nelson, Mark Lewis, \& Jennifer Phuong. 2018. Raciolinguistic chronotopes and the education of Latinx students: Resistance and anxiety in a bilingual school. Language and Communication 62. 15-25.

Flores, Nelson \& Jonathan Rosa. 2015. Undoing appropriateness: Raciolinguistic ideologies and language diversity in education. Harvard Educational Review 85(2). 149-171.

Flores, Nelson \& Jonathan Rosa. 2019. Bringing race into second language acquisition. Modern Language Journal 103. 145-151.

García, Ofelia. 2009. Bilingual education in the 21st century: A global perspective. Chichester (UK): Wiley-Blackwell.

García, Ofelia \& Naomi Kano. 2014. Translanguaging as process and pedagogy: Developing the English writing of Japanese students in the US. In Jean Conteh \& Gabriela Meier (eds.), The multilingual turn in languages education: Opportunities and challenges, 258-277. Bristol (UK): Multilingual Matters.

García, Ofelia and Tatyana Kleyn. 2016. Translanguaging with multilingual students: Learning from classroom moments. New York: Routledge. https://doi.org/10.4324/9781315695242.

García, Ofelia, \& Li Wei. 2014. Translanguaging: Language, bilingualism and education. Basingstoke (UK): Palgrave Macmillian. https://doi.org/10.1057/9781137385765.

García, Ofelia \& Ricardo Otheguy. 2020. Plurilingualism and translanguaging: Commonalities and divergences. International Journal of Bilingual Education and Bilingualism 23(1). 17-35.

Hawkins, Margaret R., \& Junko Mori. 2018. Considering 'trans-' perspectives in language theories and practices. Applied Linguistics 39(1). 1-8.

Hornberger, Nancy H., \& Holly Link. 2012. Translanguaging and transnational literacies in multilingual classrooms: A biliteracy lens. Theory into Practice 51. 239-247.

Inoue, Miyako. 2003. The listening subject of Japanese modernity and his auditory double: Citing, sighting, and siting the modern Japanese woman. Cultural Anthropology 18(2). 156-193.

Jaspers, Jürgen. 2018. The transformative limits of translanguaging. Language and Communication 58. 1-10.

Jordan, B., \& A. Henderson. 1995. Interaction analysis: Foundations and practice. Journal of the Learning Sciences 4(1). 39-103.

Krulatz, Anna\& Jonas Iversen. 2019. Building inclusive language classroom spaces through multilingual writing practices for newly-arrived students in Norway. Scandinavian Journal of Educational Research, 1-17. https://doi.org/10.1080/00313831.2018.1557741.

Krulatz, Anna \& Eivind N. Torgersen. 2016. The role of the EFL classroom in maintaining multilingual identities: Issues and considerations in Sør-Trøndelag public schools. In S. Keyl, C. Amanti, J. Alvarez, \& E. Mackinney, (eds.), Critical views on teaching and learning English around the globe, 53-68. Charlotte (NC): Information Age. 
Kubota, Ryuko. 2016. The multi/plural turn, postcolonial theory, and neoliberal multiculturalism: Complicities and implications for applied linguistics. Applied Linguistics 37(4). 474-494.

Leung, Constant \& Guadalupe Valdés. 2019. Translanguaging and the transdisciplinary framework for language teaching and learning in a multilingual world. Modern Language Journal 103. 348-370.

Li Wei. 2018. Translanguaging as a practical theory of language. Applied Linguistics 39(1). 9-30.

Lindquist, Hein \& Audrey Osler. 2016. Navigating race and ethnicity in research: Working with Norwegian schools. Race Equality Teaching 33(3). 12-18.

Makalela, Leketi. 2015. Moving out of linguistic boxes: The effects of translanguaging strategies for multilingual classrooms. Language and Education 29(3). 200-217.

Mary, Latisha \& Andrea S. Young. 2017. Engaging with emergent bilinguals and their families in the pre-primary classroom to foster well-being, learning and inclusion. Language and Intercultural Communication 17(4). 455-473.

Meeuwis, Michael \& Jan Blommaert. 1994. The 'markedness model' and the absence of society: Remarks on codeswitching. Multilingua 13. 387-423.

Ministry of Education and Research. 1998. Education act. Retrieved from https://www. regjeringen.no/en/dokumenter/education-act/id213315/.

Myers-Scotton, Carol. 1993. Social motivations for codeswitching: Evidence from Africa. Oxford (UK): Clarendon Press.

Norwegian Directorate for Education and Training. 2013. English subject curriculum. Retrieved from https://www.udir.no/kl06/ENG1-03/.

Ortega, Lourdes. 2019. SLA and the study of equitable multilingualism. Modern Language Journal 103. 23-38.

Piller, Ingrid, \& Kimie Takahashi. 2011. Linguistic diversity and social inclusion. International Journal of Bilingual Education and Bilingualism 14(4). 371-381.

Rampton, Ben. 2007. Neo-Hymesian linguistic ethnography in the United Kingdom. Journal of Sociolinguistics 11(5). 584-607.

Rindal, Ulrikke. 2014. Questioning English standards: Learner attitudes and L2 choices in Norway. Multilingua 33(3-4). 313-334.

Rosa, Jonathan \& Nelson Flores. 2017. Unsettling race and language: Toward a raciolinguistic perspective. Language in Society 46(5). 621-647.

Rosiers, Kirsten, Inge Van Lancker \& Steven Delarue. 2018. Beyond the traditional scope of translanguaging: Comparing translanguaging practices in Belgian multilingual and monolingual classroom contexts. Language and Communication 61. 15-28.

Saldaña, Johnny. 2015. The coding manual for qualitative researchers, 3rd edn. London: SAGE.

Scheffler, Pawel, May O. Horverak, Weronika Krzebietke \& Sigrunn Askland. 2017. Language background and learners' attitudes to own-language use. ELT Journal 71(2). 197-217.

Schissel, Jamie L., Haley De Korne \& Mario López-Gopar. 2018. Grappling with translanguaging for teaching and assessment in culturally and linguistically diverse contexts: Teacher perspectives from Oaxaca, Mexico. International Journal of Bilingual Education and Bilingualism 1-17. https://doi.org/10.1080/13670050.2018.1463965.

Seltzer, Kate. 2019. Reconceptualizing "Home" and "school” language: Taking a critical translingual approach in the English classroom. TESOL Quarterly 1-22. https://doi.org/10. 1002/tesq.530. 
Turner, Marianne \& Angel Lin. 2017. Translanguaging and named languages: Productive tension and desire. International Journal of Bilingual Education and Bilingualism 1-11. https://doi. org/10.1080/13670050.2017.1360243.

Williams, Cen. 1994. Arfarniad o ddulliau dysgu ac addysgu yng nghyd-destun addysg uwchradd ddwyieithog [Evaluation of teaching and learning methods in the context of bilingual secondary education]. University of Wales, Bangor. 